\title{
First tracks of individual Blackcaps suggest a complex migration pattern
}

\author{
Dieter Hiemer ${ }^{1}$ - Volker Salewski ${ }^{2}$ (D) Wolfgang Fiedler $^{3} \cdot$ Steffen Hahn $^{4}$ • \\ Simeon Lisovski ${ }^{4,5}$
}

Received: 5 June 2017/Revised: 16 August 2017/Accepted: 17 August 2017/Published online: 4 September 2017

(c) Dt. Ornithologen-Gesellschaft e.V. 2017

\begin{abstract}
The Blackcap Sylvia atricapilla is a model species for the evolution of bird migration in a time of global change. However, many assumptions about putative changes to their migratory paths have not been verified because, until recently, it has not been possible to track individual small passerines throughout the entire migration cycle. With the recent development of miniaturised light-level geolocators, it is now possible to track passerines throughout the migration cycle and test these latter assumptions. We deployed 100 geolocators on Blackcaps breeding in southern Germany in 2015, and recaptured three of these birds in 2016. We used a new analytical tool implemented in the R package GeoLight to identify stopover sites during migration. One bird migrated due west to winter in southern England or possibly
\end{abstract}

Communicated by N. Chernetsov.

Electronic supplementary material The online version of this article (doi:10.1007/s10336-017-1490-3) contains supplementary material, which is available to authorized users.

Volker Salewski

Volker.Salewski@NABU.de

1 Alte Reichsstrasse 38, 91522 Ansbach, Germany

2 Michael-Otto-Institut im NABU, Goosstroot 1, 24861 Bergenhusen, Germany

3 Max-Planck-Institute for Ornithology, Am Obstberg 1, 78315 Radolfzell, Germany

4 Schweizerische Vogelwarte, Seerose 1, 6204 Sempach, Switzerland

5 Department of Neurobiology, Physiology and Behavior, University of California, Davis, CA 95616, USA northwestern France, whereas two birds migrated south towards North Africa via Italy. Although none of the retrieved geolocators collected data throughout the entire migration cycle, the data suggest that migration patterns of the species are more complex than previously thought.

Keywords Sylvia atricapilla · Geolocator · Connectivity · Migratory path · Micro-evolutionary adaptation .

Anthropogenic global change

\section{Zusammenfassung}

\section{Erste Verfolgungen individueller Zugwege von Mönchsgrasmücken lassen ein komplexes Migrationsverhalten annehmen}

Die Mönchsgrasmücke Sylvia atricapilla ist eine Modellart zur Erforschung der Evolution des Vogelzugs in Zeiten des globalen Wandels. Viele Annahmen zur vermuteten Verlagerung von Zugwegen konnten aber bisher nicht getestet werden, da es bisher nicht möglich war, individuelles Zugverhalten während eines Zugzyklus zu erfassen. Mit der Entwicklung miniaturisierter Lichtlogger ist dies nun möglich. Wir statteten 2015 einhundert in Süddeutschland brütende Mönchsgrasmücken mit Lichtloggern aus, von denen wir drei 2016 wieder fingen. Wir wendeten eine neue analytische Methode im R-Paket GeoLight an, um Ratsplätze auf dem Zug zu identifizieren. Eine Mönchsgrasmücke zog nach Westen, um in Südengland oder möglicherweise auch in Nordfrankreich zu überwintern. Zwei weitere Vögel zogen über Italien nach Nordafrika. Obwohl keiner der Logger über den gesamten Zugzyklus Daten erfasste, zeigen die Ergebnisse, dass der Zug der Mönchgrasmücke komplexer sein könnte als bisher angenommen. 


\section{Introduction}

The Blackcap Sylvia atricapilla is a model species for study of the evolution of bird migration (Berthold et al. 1992; Pulido et al. 1996; Bearhop et al. 2005). The suggested establishment of a new migration route over several decades by central European populations has become a textbook example of micro-evolutionary adaptation to anthropogenic global change (e.g. Campbell et al. 2008). The great majority of Blackcaps breeding in central Europe used to migrate southwest to spend the winter in the western Mediterranean region. Winter records in the British Isles were very scarce until the second half of the 20th century (Stafford 1956). Thereafter, the number of Blackcaps wintering in the British Isles increased (Wernham et al. 2002), and these are presumed to be of central European origin (Schlenker 1981; Berthold 1995). The new migration route towards the northwest is argued to be the result of micro-evolutionary adaptation (Berthold 1995) based on the shorter migratory distance involved, which allows earlier arrival at breeding sites. The latter is often associated with higher reproductive success (Kokko 1999) such that Blackcaps from the northwestern wintering sites may have an advantage over birds from the southwestern sites. Assortative mating between birds synchronised in their arrival times, considering that migratory directions are under genetic control (Helbig 1996), could lead to an increase in the proportion of northwestern migrants (Berthold 1995; Bearhop et al. 2005). Most likely due to high winter mortality, migration of central European Blackcaps to the British Isles was not adaptive before the second half of the 20th century. Since then, rising winter temperatures as well as improved food availability due to an increasing number of bird feeders is assumed to have increased the survival rate of Blackcaps wintering in the British Isles (Terrill and Berthold 1990; Berthold 1995; Mettler et al. 2013).

While the above scenario is plausible, its underlying assumptions have never been verified because, until recently, it was not possible to track individual small passerines throughout the entire migration cycle. Bearhop et al. (2005) and Rolshausen et al. (2009, 2010) assigned individual birds to wintering areas on the Iberian Peninsula or the British Isles using stable hydrogen isotopes $\left(\delta^{2} \mathrm{H}\right)$. While this method allows geographical classifications resembling those of the location where the studied tissues grew, it does not provide details of migration routes and phenology. Moreover, based on the similar $\delta^{2} \mathrm{H}$ signatures of local precipitation, birds wintering in the British Isles cannot be separated from those wintering in France or even parts of central Spain, and those wintering in Spain and Portugal cannot be separated from those wintering in North
Fig. 1 Representation of the logic of the siteEstimate function used to calculate the likelihood of locations of a series of sunrise and sunset times across a stationary period. a Sunrise and sunset times from a known location (here, the breeding site in southern Germany of three tracked European Blackcaps) can be used to calculate the error distribution by detecting the true sunrise and sunset time, as well as the sun elevation angle for the first and last detected twilight event (i.e. twilight error $=0$ ). Histogram shows the pooled twilight error for all three individuals and fitted $\gamma$ (dotted line) and log-normal (solid line) distribution. b Results of movement analysis (for bird 15KU) using the changeLight function within the $\mathrm{R}$ package GeoLight indicating two stationary periods, of which the first is at the known breeding site. c Raw geolocator data (grey indicating the light value, $y$-axis hours of the day, $x$-axis days over the tracking period). Open circles are sunrise and sunset times with the dashed lines showing the fitted sunrises and sunsets for the stationary periods. d Spatial output of the siteEstimate function with most likely location based on the above-estimated sun elevation angle; error bars $\pm 1^{\circ}$. For comparison, circles are location estimates based on the commonly used thresholdbased algorithms (e.g. coord function in GeoLight)

Africa, southern France or northern Italy (see Fig. 1 in Bearhop et al. 2005). Stable isotope signatures reflect the composition of food ingested during the synthesis of tissues. In the case of the wintering sites in the British Isles, the diet is significantly topped up by commercial food in bird feeders (Chamberlain et al. 2005), which is of unknown origin and its isotope signatures may differ from the stable isotope composition of the natural resources at the wintering site.

Tracking of individual migration is paramount to clarifying details of the putative novel migration route of Blackcaps and the underlying micro-evolutionary processes. This has become possible with the recent development of miniaturised light-level geolocators (Bridge et al. 2011). We equipped Blackcaps breeding in southern Germany with geolocators to identify migration routes and wintering areas. Here we present the results for three birds that indicate that Blackcap migration is complex with respect to direction and phenology.

\section{Methods}

\section{Study site, geolocator deployment and retrieval}

Light-level geolocators (hereafter "geolocators") were deployed on individual Blackcaps breeding in a forest near Ansbach, southern Germany $\left(49.306^{\circ} \mathrm{N}, 10.613^{\circ} \mathrm{E}\right)$. The forest (ca. 20 ha) is characterized by ca. 80-year-old Norway spruce (Picea abies), Scots pine (Pinus sylvestris), common beech (Fagus sylvatica) and pedunculate oak (Quercus robur) trees, as well as a dense understory of black elder (Sambucus nigra), raspberries and blackberries (Rubus spp.). Blackcaps were caught at their nests using 


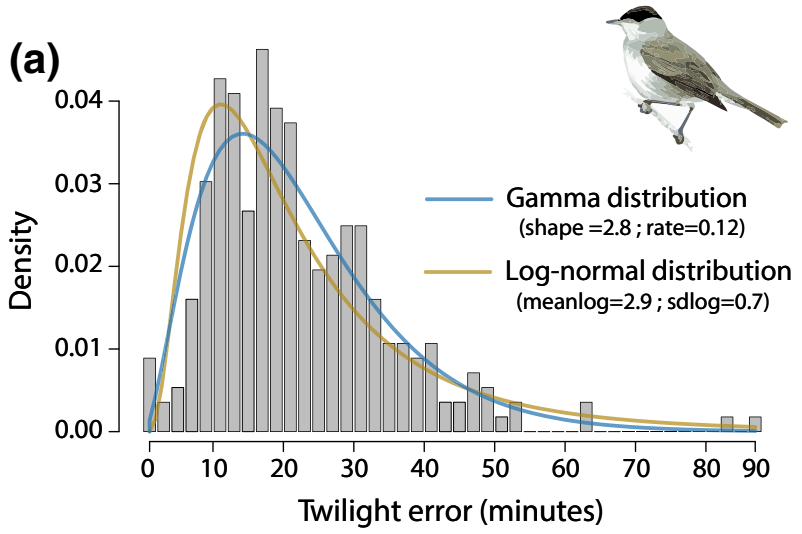

(b)

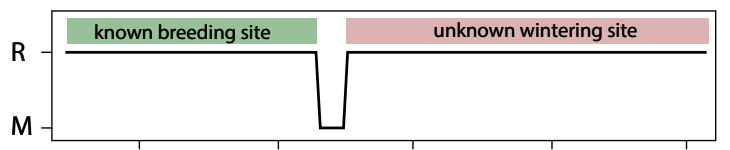

(c)
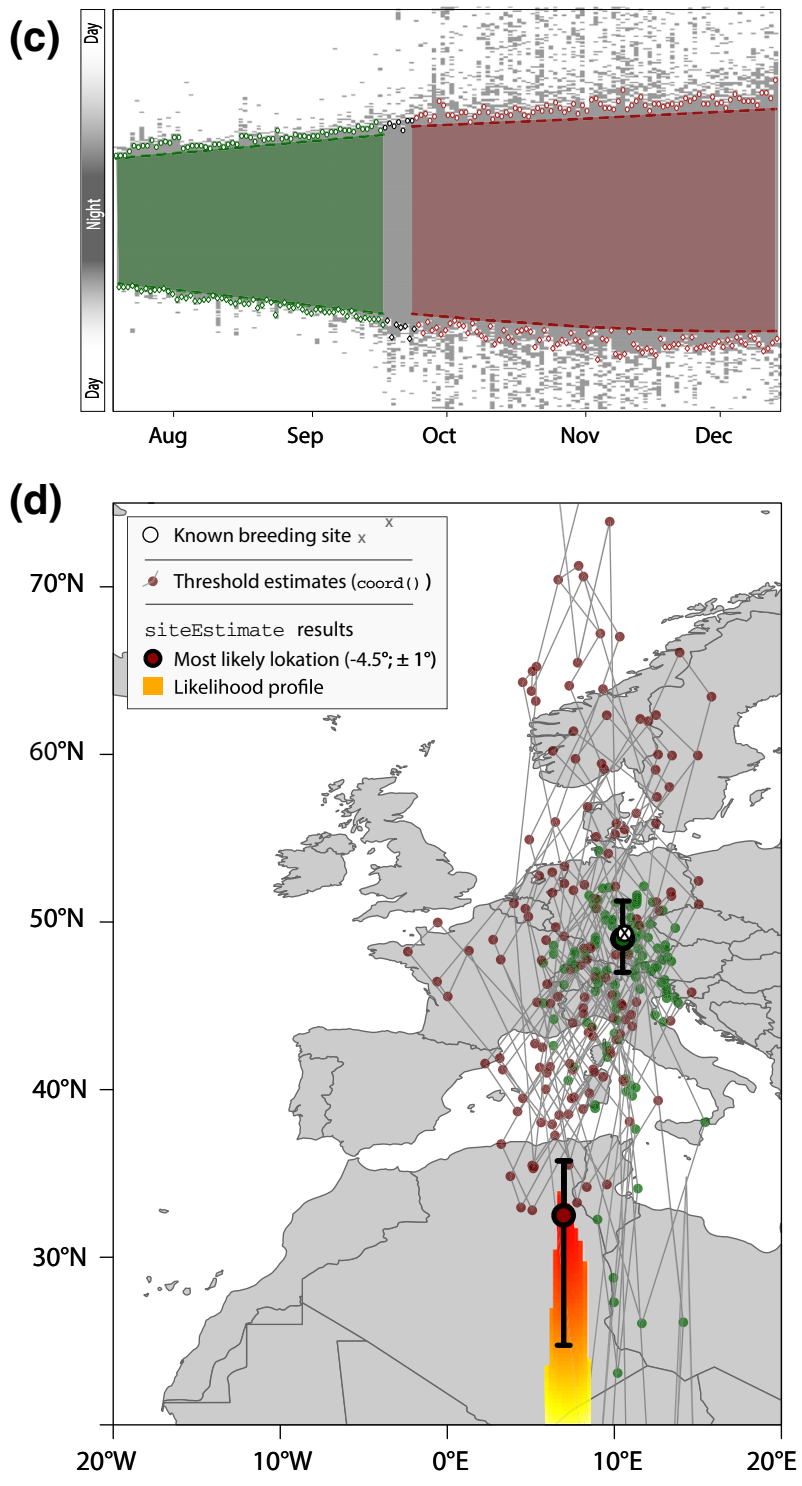

mist nets in spring 2015. Therefore, only individuals in active breeding mode were equipped with geolocators, thus excluding migrants that might transit through the area during the beginning of the breeding season (Bairlein 1978). Geolocators (SOI GDL2; Swiss Ornithological Institute) were deployed on 100 Blackcaps (50 males, 50 females) using a leg-loop harness (Rappole and Tipton 1990). Intensive mist-netting took place in spring 2016 to retrieve the geolocators. Unfortunately, Blackcaps were breeding in very low numbers during the breeding season of 2016, so few were caught; only three Blackcaps carrying a geolocator were recaptured (15KU, 17AT, 17CO). The reduced breeding numbers were probably due to unusually cold and wet conditions in April and early May. Many of the earlier breeding attempts of these birds failed and they probably left the area, whereas others presumably did not start breeding at all. Recapture probability of Blackcaps in the study area was much higher between years at $47 \pm 5 \%$ from 2003 to 2014 (Hiemer and Salewski, unpublished data).

None of the retrieved geolocators collected data through the entire non-breeding period. Geolocator recordings ended on the 6 and 17 December 2015 for $15 \mathrm{KU}$ and 17AT, respectively, and on 25 January 2016 (17CO). Geolocator $17 \mathrm{CO}$ also failed to record data between the 28 July and 17 September, so that the departure date could not be estimated for this bird.

\section{Geolocator analysis}

Data were downloaded from the three retrieved geolocators, and sunrise/sunset times were defined using a light intensity threshold of 1 (arbitrary units). We first estimated locations using the threshold method and the function implemented in the $\mathrm{R}$ package GeoLight (Lisovski and Hahn 2012). However, potentially strong shading caused by the dense habitat of Blackcaps, as well as short migratory distances, resulted in location estimates that did not show clear stopover or wintering sites.

We therefore developed an alternative approach to estimate a location for each stopover or wintering site (i.e. stationary period). Migratory birds perform flights between periods of residency that are used for resting or to replenish their fuel resources (Newton 2008). The method introduced here exploits this behaviour by using all sunrise and sunset times in a stationary period as information to estimate a location instead of estimating one location per twilight time. Furthermore, the method exploits the fact that geolocators should be unable to detect sunrise before the real sunrise event (and sunset after the real sunset event) and that all errors in twilight times are therefore positive during sunrise and negative during sunset (i.e. shading 
causes sunrise to be detected later and sunset to be detected earlier). We can use this information to evaluate the possibility that a series of twilight times was recorded at a specific location with a certain sun elevation angle and a specific error distribution for each location on earth. To this end, calibration data are needed, i.e. light intensity measures and ultimately sunrise and sunset times recorded at known locations, usually after deployment, or before retrieval of the geolocator. The twilight errors derived from the calibration data can be described using $\gamma$ or log-normal distributions (Fig. 1a). The method has been implemented in a new version of GeoLight (version 2.01) and the function siteEstimate allows application of the method to twilight events during stationary periods. The Online Resource provides more detailed descriptions and code, as well as an evaluation using data from Black-tailed Godwit Limosa limosa carrying both a global positioning system and a geolocator device (Rakhimberdiev et al. 2016).

We used the function changeLight to distinguish between periods of residency and periods of movement, and applied the siteEstimate function to each of the stationary periods. The sun elevation angle was established for each individual $\left(17 \mathrm{AT}-4.2^{\circ}, 17 \mathrm{CO}-6.25^{\circ}, 15 \mathrm{KU}\right.$ $-5^{\circ}$ ) using the first stationary period after deployment (i.e. the breeding site). To provide an estimate of uncertainty, we also estimated the location for each site with the respective sun elevation angle $\pm 1^{\circ}$. Great circle distances between stationary sites, as well as arrival and departure dates, are only rough estimates.

\section{Results}

Three Blackcaps equipped with geolocators showed diverse migration patterns with respect to phenology, direction and presumed wintering area (Fig. 2). 17AT (female) and $15 \mathrm{KU}$ (female) left the breeding site on 16 and 26 September, respectively, and migrated either due west (15KU) towards England (with a slight possibility that the destination was in northwestern France), or almost due south (17AT) to the border between Tunisia and Algeria (Fig. 2). Migration is estimated to have taken 6-7 days for each individual. The distances between the breeding grounds and the two staging sites were ca. $780 \mathrm{~km}$ for $15 \mathrm{KU}$ and ca. $1790 \mathrm{~km}$ for $17 \mathrm{AT}$.

The first detectable stopover site of 17CO (male) was in northeastern Algeria. Hence, we assume a southward orientation after leaving the breeding site, similar to that seen in $15 \mathrm{KU}$, which migrated to North Africa across Italy and the Mediterranean. In contrast to the other two individuals, $17 \mathrm{CO}$ resumed migration after 11 days at the first detectable stopover and moved westwards with two further stopovers in north Algeria (31 days) and in the region of

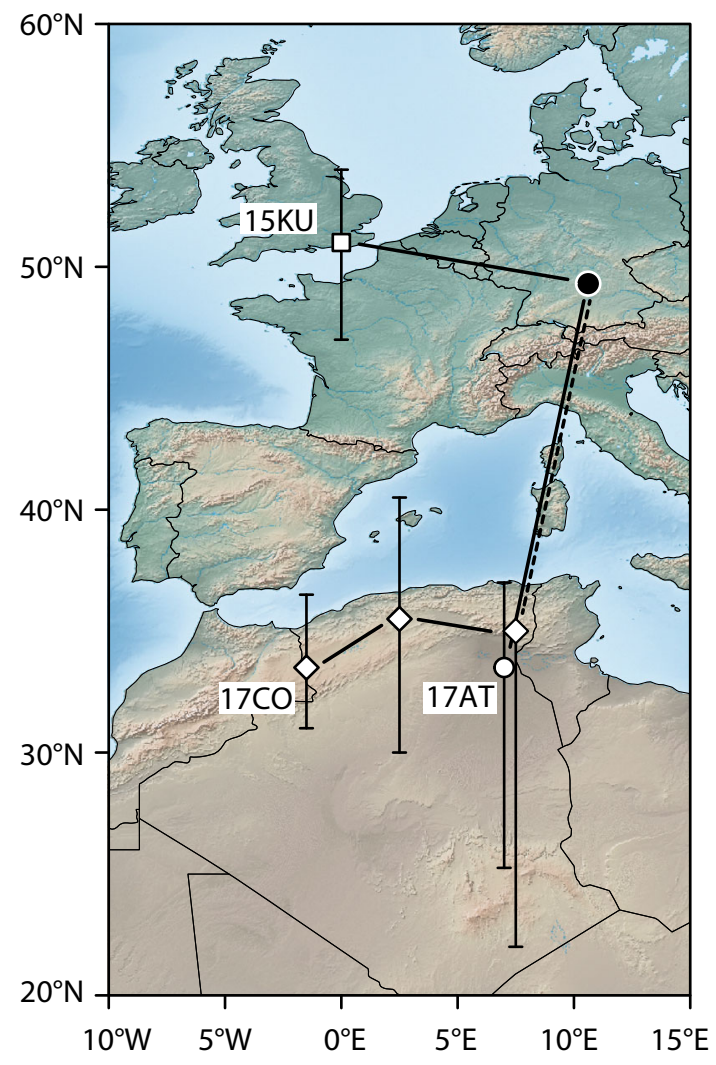

Fig. 2 Estimated migration routes of three European Blackcaps that breed in southern Germany. Stationary periods were distinguished using changeLight, and locations estimated using the new siteEstimate function implemented in R package GeoLight. Stationary sites are connected by lines; dashed line indicates missing data between the indicated sites. Error bars indicate most likely latitude with a sun elevation angle of $\pm 1^{\circ}$

the Algerian-Moroccan border where the bird arrived approximately on 15 November (Fig. 2). The distance between the breeding site and each of the three staging sites on migration were ca. $1610 \mathrm{~km}$, ca. $2070 \mathrm{~km}$ and ca. $2500 \mathrm{~km}$, respectively.

\section{Discussion}

Although we retrieved only three geolocators, and these did not record entire migration cycles, the results show that Blackcap migration is complex and that assigning central European Blackcaps to either of two wintering regions, on the British Isles or the Iberian Peninsula, may miss the diversity of migration routes. The latter was already suggested by analyses of ring recoveries (Zink 1973; Rost 2009; Bairlein et al. 2014).

Two individuals migrated due south, most likely via Italy to northwestern Africa. Ring recoveries have already indicated that an unknown proportion of Blackcaps breeding in southern Germany take this route via Italy into 
Africa (Zink 1973; Bairlein et al. 2014) and given our results, this may indeed be an important migration route. One bird, however, migrated due west and most likely stayed in southern England, although northwestern France cannot be excluded.

The long sojourn between the arrival at the first staging site and the failure of the loggers suggest that $15 \mathrm{KU}$ and 17AT reached their final wintering sites in one migration step. The distance of ca. $2000 \mathrm{~km}$ between the two wintering sites indicates that there is no specific wintering area for this population and probably no connectivity between breeding sites and wintering areas for central European blackcap populations. Migratory directions are, however, under genetic control (Helbig 1996). Whether the southward migration of some individuals indicates that the studied population lies within a hybrid zone of southwestern and southeastern migrants (Helbig 1996), and what proportion of birds migrate northwest, can only be answered with a larger sample size that includes birds from other breeding areas.

Given the similarity of mean annual $\delta^{2} \mathrm{H}$ in rainfall at locations on the Iberian Peninsula, in Italy and North Africa, and at locations in Ireland, southeastern England, central France and even central Spain (Fig. 1 in Bearhop et al. 2005), it is difficult to distinguish between wintering sites based on $\delta^{2} \mathrm{H}$ ratios in Blackcap tissues. Although the first staging site of $15 \mathrm{KU}$ was much closer to the breeding grounds than the first staging site of $17 \mathrm{AT}$, estimating migration distances via stable isotope signatures is questionable. Individuals that winter in southeastern England migrate a quite different distance to those that winter in western Ireland, and Ireland is not necessarily closer to the breeding grounds in southwestern Germany than is central Spain. Similarly, southern German blackcaps wintering in southern and western France (Bairlein et al. 2014) could have a similar isotope signature to birds wintering in Spain, but migrate a much shorter distance. Thus, only tracking studies should be used to draw conclusions about migration distance and its contribution to the evolution of new migration strategies.

In conclusion, though our data are limited, we have shown that the use of geolocators together with appropriate methods for analysis of data may provide more insights into Blackcap migration patterns in the future. This will allow better insights into the plasticity of bird migration in a rapidly changing world.

Acknowledgements We are very grateful to a private donor who funded a large part of the cost of the light loggers. The geolocator development was financially supported by the Swiss Federal Office for Environment (UTF 254.08.08). D. Franklin kindly improved the English.

\section{References}

Bairlein F (1978) Über die Biologie einer südwestdeutschen Population der Mönchsgrasmücke. J Ornithol 119:14-51

Bairlein F, Dierschke J, Dierschke V, Salewski V, Geiter O, Hüppop K, Köppen U, Fiedler W (2014) Atlas des VogelzugsRingfunde deutscher Brut- und Gastvögel. AULA, Wiebelsheim

Bearhop S, Fiedler W, Furness RW, Voitier SC, Waldron S, Newton J, Bowen GJ, Berthold P, Farnsworth K (2005) Assortative mating as a mechanism for rapid evolution of a migratory divide. Science 310:502-504

Berthold P (1995) Microevolution of migratory behaviour illustrated by the Blackcap Sylvia atricapilla: 1993 Witherby Lecture. Bird Study 42:89-100

Berthold P, Helbig AJ, Mohr G, Querner U (1992) Rapid microevolution of migratory behaviour in a wild bird species. Nature 360:668-670

Bridge ES, Thorup K, Bowlin MS, Chilson PB, Diehl RH, Fléron RW, Hartl P, Kays R, Kelly JF, Robinson WD, Wikelski M (2011) Technology on the move: recent and forthcoming innovations for tracking migratory birds. Bioscience 61:689-698

Campbell NA, Reece JB, Urry LA, Cain ML, Wasserman SA, Minorsky PV, Jackson RB (2008) Biology. Benjamin Cummings, San Francisco

Chamberlain DE, Vickery JA, Glue DE, Robinson RA, Conway GJ, Woodburn RJW, Cannon AR (2005) Annual and seasonal trends in the use of garden feeders by birds in winter. Ibis 147:563-575

Helbig AJ (1996) Genetic basis, mode of inheritance and evolutionary changes of migratory directions in Palearctic warblers (Aves: Sylviidae). J Exp Biol 199:49-55

Kokko H (1999) Competition for early arrival in birds. J Anim Ecol 68:940-950

Lisovski S, Hahn S (2012) GeoLight-processing and analysing lightbased geolocator data in R. Methods Ecol Evol 3:1055-1059

Mettler R, Schaefer HM, Chernetsov N, Fiedler W, Hobson KA, Ilieva M, Imhof E, Johnsen A, Renner SW, Rolshausen G, Serrano D, Wesołowski T, Segelbacher G (2013) Contrasting patterns of genetic differentiation among Blackcaps (Sylvia atricapilla) with divergent migratory orientations in Europe. PLoS One 11:e81365

Newton I (2008) The migration ecology of birds. Elsevier, Amsterdam

Pulido F, Berthold P, van Noordwijk AJ (1996) Frequency of migrants and migratory activity are genetically correlated in a bird population: evolutionary implications. Proc Natl Acad Sci 93:14642-14647

Rakhimberdiev E, Senner NR, Verhoeven MA, Winkler DW, Bouten W, Piersma T (2016) Comparing inferences of solar geolocation data against high-precision GPS data: annual movements of a double-tagged black-tailed godwit. J Avian Biol 47:589-596

Rappole JH, Tipton A (1990) New harness design for attachment of radio transmitters to small passerines. J Field Ornithol 62:335-337

Rolshausen G, Segelbacher G, Hobson KA, Schaefer HM (2009) Contemporary evolution of reproductive isolation and phenotypic divergence in sympatry along a migratory divide. Current Biol 19:2097-2101

Rolshausen G, Hobson KA, Schaefer HM (2010) Spring arrival along a migratory divide of sympatric blackcaps (Sylvia atricapilla). Oecologia 162:175-183

Rost F (2009) Das Zugverhalten europäischer Mönchsgrasmücken Sylvia atricapilla im Wandel-Daten aus Ostdeutschland 1964-2007. Ber Vogelwarte Hiddensee 19:21-35 
Schlenker R (1981) Verlagerung der Zugwege von Teilen der südwestdeutschen und österreichischen Mönchsgrasmücken (Sylvia atricapilla)—Population. Ökol Vögel 3:314-318

Stafford J (1956) The wintering of blackcaps in the British Isles. Bird Study 3:251-257

Terrill SB, Berthold P (1990) Ecophysiological aspects of rapid population growth in a novel migratory blackcap (Sylvia atricapilla) population: an experimental approach. Oecologia $85: 266-270$

Wernham CV, Toms MP, Marchant JH, Clark JA, Siriwardena GM, Baillie SR (2002) The migration atlas: movements and birds in Britain and Ireland. T \& AD Poyser, London

Zink G (1973) Der Zug europäischer Singvögel. 1. Lieferung. MaxPlanck-Institut für Verhaltensphysiologie, Radolfzell 